\title{
Electro-Rheological Properties of Liquid Crystal in High Shear Rate Region
}

\author{
Takatsune NARumi, Hiroyoshi MAEdA, Hiroyuki YoshIZAwA, and Tomiichi HASEGAwA \\ Department of Mechanical and Production Engineering, Faculty of Engineering, Niigata University, \\ 8050, 2-no-cho Ikarashi, Niigata 950-2181, Japan
}

\begin{abstract}
Electro-rheological properties of liquid crystals have been investigated utilizing a parallel-plate type rheometer and a two-dimensional minute channel. A liquid crystal with high specific resistance (LC only) and that with a conductive dopant $(\mathrm{LC}+\mathrm{TBAB})$ were tested in order to clarify the influence of electric instability on the ER effect. Flow curves including shear-thinning region were empirically modeled with Carreau type equation from parallel plate test, and the ER effects in the minute channel were numerically predicted with the model. In the case of LC only, the prediction of the model was in good agreement with the experimental. Lower ER effect was obtained with LC+TBAB under DC electric field, where the electroconvection was generated, and the model was partially useful for the prediction. In this case, the influence of the electric field strength on the characteristic time of the model was more complicated than that of the LC only. The transient response of the ER effect at the onset of the electric field was also measured, and almost same response was obtained for all conditions in our test.
\end{abstract}

Key Words: Liquid crystal / Electro-rheological effect / Empirical model / Transient response / Electroconvection

\section{液晶の高せん断速度域での ER 特性}

\author{
鳴海 敬倫 ${ }^{*}$ ，前田 浩芳**，吉沢 博之*** 長谷川 富市*
}

(原稿受理 : 2006年11月 14日)

1. 緒言

外場によりそのレオロジー特性を制御できる機能性流体 は, 学術的にも応用的にも興味深い材料である. 外場として 電場を用いるER（Electro-rheological）流体については，これ までにその機能発生メカニズムからデバイス応用に至るま でさまざまな研究がなされてきた. e.g. 1-3)これまで粒子分散系 ER流体に関する研究が多くなされているが, 実際の実用化に はいくつかの問題が残されている. 一つには粒子の沈降・分 散安定性の問題があり, また, MR 流体と比べ発生荷重（応 力）が低い点も問題とされる. しかし, 電極のみで外場をか けることができることから, デバイスのマイクロ化に適す利 点も有する. この場合, 慣性力の影響の少ない範囲での利用 が見込まれ, 発生荷重が小さくても応用が可能と考えられ る.ところで, このようなマイクロ流動への応用を考えた場 合, 粒子分散系ER流体は, 凝集などの問題にあわせて, 粒子 径が利用できる最小寸法に影響するため, マイクロマシンの ようなさらに微少なサイズまでの応用は難しくなる. 均一系 のER流体の代表である液晶は分子の電気的な異方性により

\footnotetext{
$*$ 新潟大学工学部 $\overline{7} 950-2181$ 新潟市五十嵐 2 の町 8050

E-mail: narumi@eng.niigata-u.ac.jp

** 現所属：(株) ジェイテクト † 542-8502 大阪市中央区南船場 3-5-8

*** 現所属 : 富士重工業（株） ₹ 160-8316 新宿区西新宿 1-7-2
}

ER効果を生じるため, このような問題が生じない. 低分子液 晶は, 粒子分散系よりも発生応力はさらに低く, かつ降伏特 性を有しない点など不利点もあるが，このようにミクロサイ ズの流路への応用には最も適していると考えられる. なお, 高い発生応力が得られる高分子液晶もER流体として開発さ れ，実用に供されているが4-6，粘度が高くマイクロ構造内で の利用には適さない.

液晶のER効果の発生メカニズムはMiesowiczの粘度7) とし て知られるせん断方向に対する分子の配向方向の違いによ る粘度変化として理解されている. よって, 液晶のER効果を 述べる際の多くは，せん断速度一定で電界強度を上げた際の ニュートン粘性からニュートン粘性への変化として記述さ れる.8)このため, レオロジー的な興味はあまり持たれず，実 際的な現象である一定電場下でせん断速度に対するER特性 の変化過程という観点からの研究はほとんどなされていな い. すなわち, 上記の粘度増加過程は, 本論文内で示すせん 断速度による shear thinning 領域での変化に対応するが，この 領域に関する議論はほとんどない。 また, 低分子液晶のER流 体としての応用に関寸る研究は, ダンパー9), 潤滑 ${ }^{10)}$, マイク ロアクチュエータ11) ヘなどいくつかみられるが, いずれの場 合もニュートン粘性からニュートン粘性への変化を前提と したものであり, 粘度のせん断速度依存性を意識した応用は 見あたらない.さらにサイズの小さいマイクロデバイスへの 
応用などを考えた場合，せん断速度は必然的に高くなり，そ の領域での流動特性を解明しておくことが重要となる.

一方，液晶は，密閉空間内での利用ではその特性の劣化は 非常に少ないが, ER流体としてのメカニカルな利用を考えた 場合, 様々な物質との接触や異物等の混入などが考えられ る. その結果として, 電気的特性の変化なども予想される. このような状況でのER効果の変化を知っておくことは, 実用 上も重要と考えられるが, この種のデータはほとんどない. さらに, 液晶のミクロ挙動は解析的に扱うことも可能である が，簡便なモデルで流動特性を表すことができれば，デバイ ス開発などの応用的には有利である.

そこで本研究では, 電場下での低分子液晶のレオロジー特 性について, 高せん断速度域も含む, 広い範囲での見掛けの 粘度変化を明らかにし, さらに実験式的なモデルを得ること を主な目的とした. また, 比抵抗の高い本来の液晶と導電性 ドーパントを加え, 比抵抗が下がったケースで電気対流現 象が生じる場合のER特性についても検討した. さらに, そ れぞれの場合の電場印加時の過渡応答についても明らかに した.

\section{2. 実 験}

\section{1 供試流体}

実験にはチッソ（株）から提供いただいた誘電異方性 $(\Delta \varepsilon)$ が正の液晶JC-1009XXを用いた. 以下, 簡略化と比較のためLC only と表記する. その主な特性をTable Iに示す.さらにこの液 晶に, 導電性ドーパントTBAB [ Tetrabutylammonium Bromide ] を重量濃度で 100 ppm添加したもの（以下，LC+TBAB）も実 験に供した. LC+TBABはLC onlyに対して比抵抗は数十分の 一になっていると考えられる. ${ }^{12)}$ Fig. 1に流れがない場合の直 流電場下での液晶の状態を写真撮影した例を示す. 2枚のITO ガラス電極で液晶をはさみ, 電場印加された状態をクロスニ コルの偏光状態で透過光を撮影した結果である. Fig. 1(a)の LC onlyの場合は透過光が完全に遮断されており, 電場方向に 十分に配向していることがわかる. 一方, Fig. 1(b)では電荷の 電場方向への移動により誘起される電気対流が観察された. この状態は液晶ディスプレイの開発段階で研究された動的 散乱モード; DSM（Dynamic Scattering Mode）と同一のものと 考えられる.13)

Table I. Material constants of liquid crystal(LC only) tested.

\begin{tabular}{|c|c|}
\hline $\begin{array}{c}\text { Phase transition } \\
\text { temperature } \\
\text { (nematic-isotropic) }\end{array}$ & $72.2^{\circ} \mathrm{C}$ \\
\hline Viscosity $\left(20^{\circ} \mathrm{C}\right)$ & $\eta_{\mathrm{eo}}: 29.1(\mathrm{mPa} \cdot \mathrm{s})$ \\
\hline Density & $10^{3}\left(\mathrm{~kg} / \mathrm{m}^{3}\right)$ \\
\hline $\begin{array}{c}\text { Refractive anisotropy } \\
\left(\lambda=589 \mathrm{~nm}, 25^{\circ} \mathrm{C}\right)\end{array}$ & $\begin{array}{c}\Delta \mathrm{n}: 0.160, \\
\mathrm{n}_{\mathrm{o}}: 1.512\end{array}$ \\
\hline $\begin{array}{c}\text { Dielectric anisotropy } \\
\left(1 \mathrm{kHz}, 25^{\circ} \mathrm{C}\right)\end{array}$ & $\Delta \varepsilon: 5.6, \varepsilon_{\perp}: 4.4$ \\
\hline
\end{tabular}

\section{2 実験装置および方法}

液晶のER特性を算定するために 2 種類の流れ場を用いた. 一つはCouette 的な流れ場に対応する平行二円板間の流れで ある. Fig. 2に示すように平行二円板間（直径 $35 \mathrm{~mm}$ ）に電場 が印加できるように改造したレオメータ（HAAKE RS50）を 用いている. 電場は上部円板上の容器に入れられた電解液を

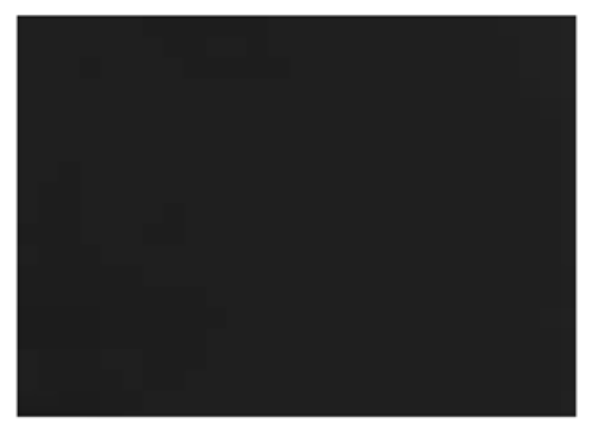

(a) LC only $(1.4 \times 1 \mathrm{~mm})$

\section{Molecular alignment}

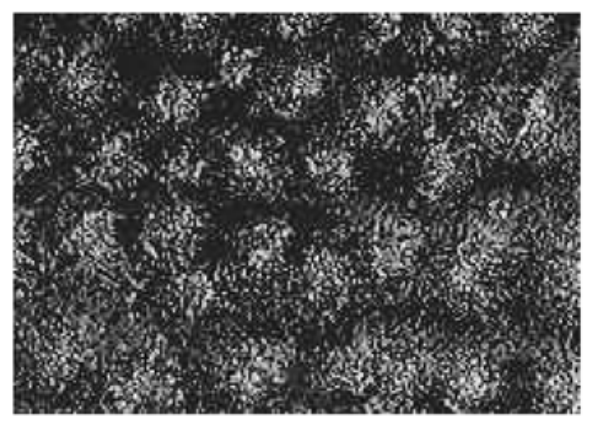

(b) LC+TBAB $(1.4 \times 1 \mathrm{~mm})$

\section{Electroconvection}

Fig. 1. Optical patterns observed with crossed polarizers without main flow under DC $1.5 \mathrm{kV} / \mathrm{mm}$.

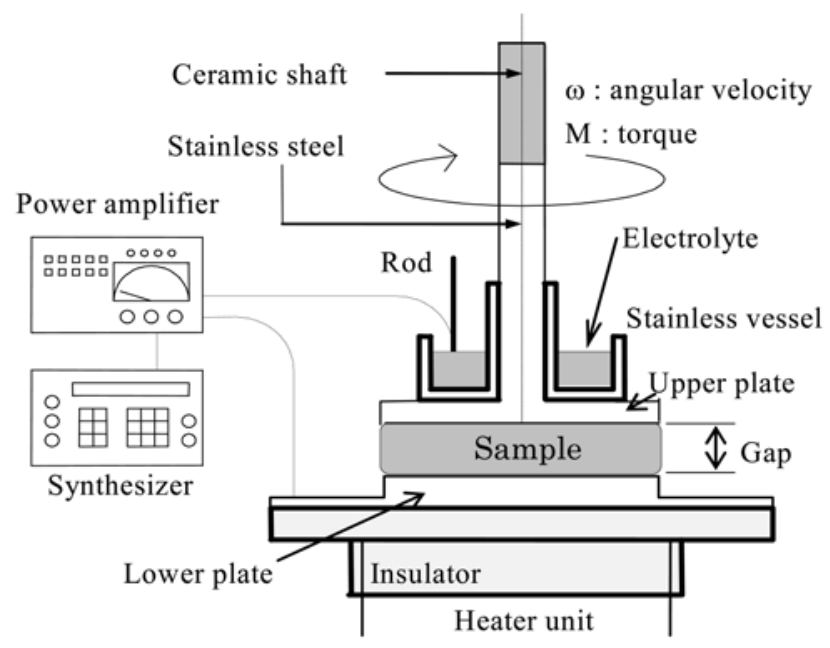

Fig. 2. Schema of the main part of the "Couette Type" experimental apparatus. 
介して印加され，その電圧，波形などはシンセサイザーと アンプで調整される．実験では上部円板が高電圧側，下部円 板が接地側となるよう電源を接続した. 印加電圧は主に電界 強度で $0 \sim 1.5 \mathrm{kV} / \mathrm{mm}$ ，周波数 0 (直流）～1 kHzの間で実験を 行った。 なお，ある程度高い周波数では結果に大きな差がな かったため, 本報では交流の実験結果としては周波数 $1 \mathrm{kHz}$ の 結果を用いて述べる. 実験で用いたすきまは50 $\mu \mathrm{m}$ から $100 \mu \mathrm{m}$ の間とし, 多くの場合, 次に示す 2 次元流れの寸きまの実験 と対応するように調整した。 なお，すきまがこの範囲内であ れば液晶のER効果の実験結果に影響がないことは実験的に 確認した。このケースを論文中では“Couette Type”と呼ぶ.

もう一つは2次元流路内の圧力下の流れである. Fig. 3に実 験装置を示す. Fig. 3(a)に示すように試験部は，2枚のITOガ ラス電極を微小なすきまを空けて張り合わせたものである. 本研究で用いた試験部は，電極間の寸きまが約 $50 \mu \mathrm{m}$, 幅, 長 さは約 $10 \mathrm{~mm}$ となっている.流路はこのガラス電極をアクリ ル板に接着し，周りを接着剤で整形したものであり，この流 出側には，流量測定用の目盛り付きピペット管が取り付けら れている.このピペット管内を試料が一定体積流れるのに要 する時間を測定し, 流量を算出した. Fig. 3(b)は実験装置全体 図である.上流側のリザーブタンク内の試料は，空気圧に よって流路部へ供給され，そのときの圧力は上流側の水銀柱 マノメータによって測定される．また試験部での流動状態が 観察できるように, 流路全体が偏光顕微鏡に取り付けてある. 印加電圧の条件はCouette Typeの実験の場合と同じである.ま た電圧を印加したときの応答性の測定も行っているが，この 場合はピペット管内の試料の移動する様子を高速度ビデオ カメラで撮影し, 液柱先端の移動量より流速を算出した. こ の後者のケースを論文中では “Poiseuille Type” と称する. な

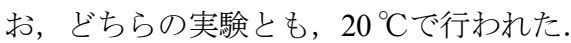

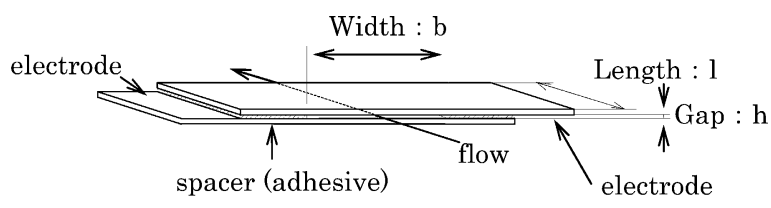

(a) test channel

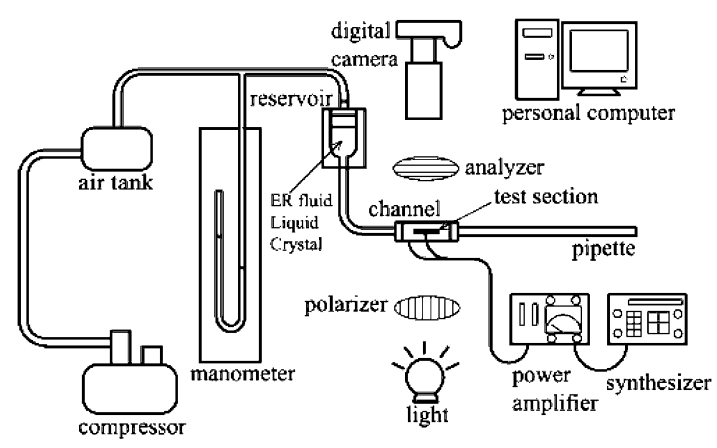

(b) schema of the setup

Fig. 3. Schema of apparatus for the 2-dimensional "Poiseuille Type" experiment.

\section{3. 実験結果および考察}

\section{1 平行二円板間の流れ (Couette Type)におけるER効果}

まず，LC onlyに対し，直流電場下で，レオメータにより測 定された流動曲線（せん断速度一応力）の一例をFig. 4に示 す. 図中の実線の一方は無電場時のニュートン流動（その際 の粘度を $\eta_{\mathrm{e}}$ とする)，他方は十分な電界強度が加えられた場 合のやはりニュートン流動（同様に $\eta_{\mathrm{e}}$ ) を表している. 先に 述べたように，この間の粘度変化についての検討例はほとん どなく，図からわかるように一定の電界強度の下ではせん断 速度の増加とともに $\eta_{\mathrm{e}}$ に対応するラインから外れ, 無電場の 状態に近づいていく変化を示す。そして, 電界強度の強さは その直線からの逸脱位置を変化させていることがわかる．同 様の結果を, 縦軸に見かけの粘度をとり, せん断速度に対し て整理した結果をFig. 5に示す. 以下の比較を分かり易くする ために，電界強度は三段階についてのみ示しており，(a)が直 流電場，(b)が交流電場下で測定した結果である。粘度曲線と しては， shear thinning性を示し，電界強度の増加に伴い，そ のカーブが高せん断速度側にシフトする事がわかる。これは 以下のように解釈される。低せん断速度域は液晶分子を電場 方向に配向させる電気的モーメントが，流動により生じる配 向を崩す方向のモーメントに比べ十分に優位で，液晶分子が 電場方向に配向した状態であり，十分に高いせん断速度領域 はその逆に電場の影響がほとんど現れない無電場の状態に 等しい. そして，その中間の領域で，せん断速度の増加とと もに流動により生じるモーメントが優位になり，配向状態を 維持できなくなることにより見かけの粘度低下が生じたと 考えられ, 電場による拘束力と流動によるせん断力のバラン スにより状態が決まる。 よって, 電界強度の増加は, より高 いせん断速度まで配向状態を維持することなる.

この粘度変化領域を定量的に検討寸るため, 現象のモデル 化を試みた。一定電場下でのレオロジ一特性はせん断速度が 零と無限大でニュートン粘性を示している点から，例えば Carreau型のモデル14) で表しうることが予想される. そこで, 次式(1)を仮定して実験式的にモデル定数を決定した。

$$
\eta=\eta_{\mathrm{eo}}+\left(\eta_{\mathrm{e}}-\eta_{\mathrm{eo}}\right)\left(1+\lambda^{2} \cdot \dot{\gamma}^{2}\right)^{(\mathrm{n}-1) / 2}
$$

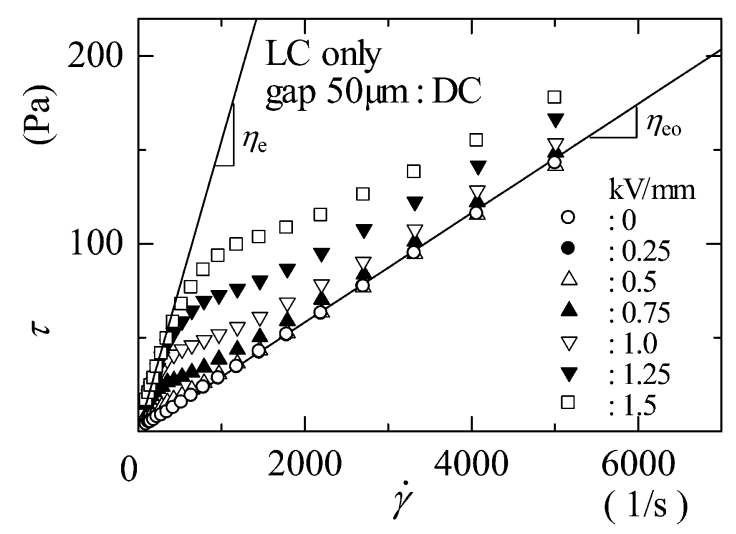

Fig. 4. Typical electro-rheological properties of liquid crystal obtained with Couette Type flow (LC only). 
ここで， $\eta_{\mathrm{e} o}$ は無電場時の粘度（分子の平均的配向方向（ディ レクター) が流れ方向をほぼ向きMiesowiczの粘度では $\eta_{1} に$ 対 応すると言われる）， $\eta_{\mathrm{e}}$ は電場下で生じるニュートン粘度 （Miesowiczの粘度ではディレクターがせん断面と直角状態に ある $\eta_{2}$ に相当）であり， $\eta_{\mathrm{e}} / \eta_{\mathrm{eo}}$ がER効果を表す. これらの值 は物性值として, 測定される值である。入は時定数であり, Fig. 5 では粘度が $\eta_{\mathrm{e}}$ を維持できなくなるせん断速度に関連し， 電界強度に依存する. これを実験式的にFig. 5から定めること も可能であるが，ここでは液晶ディスプレイなどの開発時に 用いられる光学的応答時間を導入する. 光学的応答時間 $t_{\mathrm{r}}$ と しては実験式的に導かれた ${ }^{15}$

$$
t_{\mathrm{r}}=\eta_{\mathrm{i}} /\left(\varepsilon_{0} \cdot|\Delta \varepsilon| \cdot E^{2}\right)
$$

を用いる.ここでは， $\eta_{\mathrm{i}}$ として液晶が電場方向に完全に 配向した状態での粘度 $\eta_{\mathrm{e}}$ を用いる． $\varepsilon_{0}$ は真空の誘電率 $\left(8.85 \times 10^{-12} \mathrm{~F} / \mathrm{m}\right), E$ は電界強度である。 $\lambda$ と $t_{\mathrm{r}}$ の関係は不明 であるが，便宜的に

$$
\lambda=\kappa t_{\mathrm{r}}
$$

と仮定する．ここまでの議論では未定である $n$ とにについて は, ある一つの電界強度（今回は $E=1.0 \mathrm{kV} / \mathrm{mm}$ ) のデータに フィットするように定めた. 得られたモデル定数をTable IIに 示す. なお, Fig. 5 などのせん断速度は外周部の值であるが, 平行辺板間の流れでは半径方向にせん断速度が分布する.こ の点の影響も検討したところ, せん断速度分布を考慮した結 果と外周部でのせん断速度を代表值とする結果はほぼ一致 した. ${ }^{16)} こ れ は$ 測定されるトルクに対し外周部の流れの影響 が支配的であることによるためであり，この点から本研究で は外周部のせん断速度を代表值とした結果を用いる. Fig. 5で はTable IIに示寸定数を用いて, 他の電界強度について式(1)か ら見積もられる粘度を実線で示している. $E=1.0 \mathrm{kV} / \mathrm{mm} て ゙$ 定 めた定数で異なる電界強度のデータもよく予測できること がわかる. Fig. 5(b)の交流電場のデータにはDCの予測值も破 線で示した. $\mathrm{DC}, \mathrm{AC}$ 電場それぞれの $E=1.0 \mathrm{kV} / \mathrm{mm}$ のデータ でモデル定数を定めたため, Table IIでは数值的には異なるが, Fig. 5 から直流と交流ではほぼ同じ結果が得られていること がわかる. なお, shear thinning領域の曲線の傾きに関連する $n$ が負の值として得られており, レオロジー方程式としては奇 異な結果となっている. これは電場という外場を与えた状態 での粘度変化であり, 物質の性質だけで定まる物性とは異な るものである. 物理的には電場による分子に働くモーメント などを考慮するなどして, 解釈されると考えられるが, 本論 文ではこの段階に止める.ところで, 便宜的に定めた式(3)は, Кが定数として得られた事から結果的に有効であることがわ かる. これは光学的応答時間がディスプレイでの配向状態の 変化について電気的モーメントを考慮に入れて得た結果で あることと，本実験における現象も同様のモーメントに関す る問題であることから，ほぼ対応した時定数となったと考え られる。

同様の測定をLC+TBABに対して行った結果をFig. 6 に示 す. 実線はFig. 5 の場合と同様に $E=1.0 \mathrm{kV} / \mathrm{mm}$ のデータを元に 得られたモデル定数 (Table II) 用いて予測される粘度である.
破線は比較のために示したそれぞれの電場における LC only の場合の結果である。まず, Fig. 6(a)の直流電場の結果では, LC only の場合（破線）に比べ，粘度の最大值ならびに shear thinning領域でも低い值を示している.これは以下のように解 釈される. LC+TBABでは, Fig. 1に示すような電気対流が生 じている状態での流れである.電気対流下でのER特性につい ては誘電異方性が負の液晶については報告があり, 電気対流

Table II. Model constants obtained with Couette Type tests.

\begin{tabular}{|c|c|c|c|c|}
\hline \multirow{2}{*}{} & \multicolumn{2}{|c|}{ LC only } & \multicolumn{2}{c|}{ LC+TBAB } \\
\cline { 2 - 5 } & $\mathrm{DC}$ & $\mathrm{AC}(1 \mathrm{kHz})$ & $\mathrm{DC}$ & $\mathrm{AC}(1 \mathrm{kHz})$ \\
\hline$\kappa$ & 0.66 & 0.77 & $0.025^{*}: 1.83: 1.12^{* *}$ & 0.82 \\
\hline$n$ & -0.9 & -0.71 & $-0.15^{*}:-0.2:-0.55^{* *}$ & -0.85 \\
\hline$\eta_{\mathrm{e}}(\mathrm{Pa} \cdot \mathrm{s})$ & 0.155 & 0.155 & 0.142 & 0.150 \\
\hline$\eta_{\mathrm{eo}}(\mathrm{Pa} \cdot \mathrm{s})$ & \multicolumn{4}{|c}{0.0291} \\
\hline
\end{tabular}

$\kappa$ and $n$ were obtained in the cases of $E=1.0 \mathrm{kV} / \mathrm{mm}$. Marked values were obtained with the data of respective electric field strength ( ${ }^{*} E=0.5 \mathrm{kV} / \mathrm{mm}$, $\left.{ }^{* *} E=1.5 \mathrm{kV} / \mathrm{mm}\right)$.

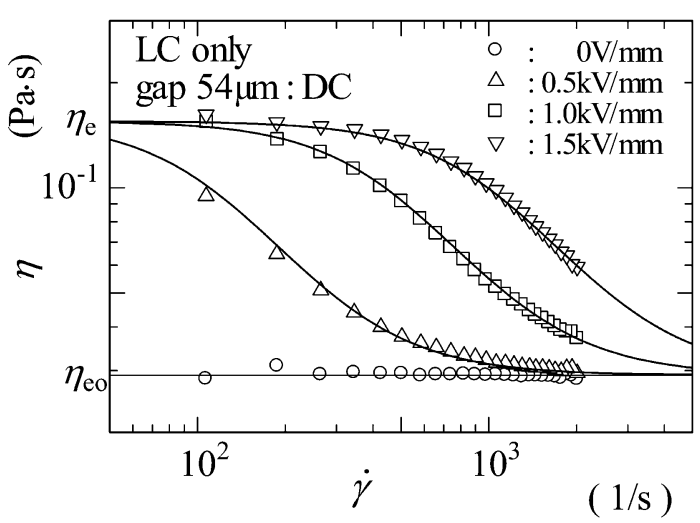

(a) DC electric field

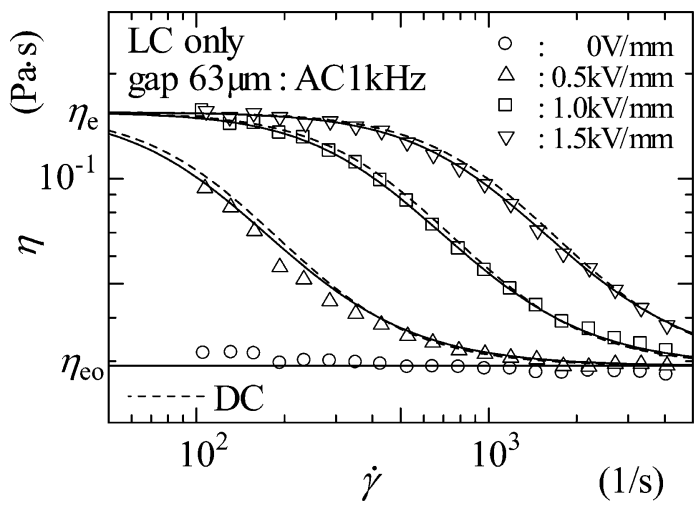

(b) AC electric field

Fig. 5. Apparent viscosity of LC only obtained with Couette Type flow. Solid lines indicate Eq. (1) estimated with parameters in Table II. The estimations under DC electric fields (= solid line in (a)) are drawn again in (b) with broken lines. 
だけではほとんどER効果が得られていない.8) 今回の結果で は, 配向状態（LC only）に近い值を示しており, ある程度配 向現象が生じていると予想される. 寸なわち, DSM現象と同 様に電荷の移動により電気的不安定性が生じ，分子配向が崩 され対流となるが，本実験のように主流が存在する場合，主 流により電気対流が押さえられていると考えられる.ただ し, その電気的不安定性は配向を崩し易くするため, LC only の場合よりも最大值でもER効果が落ち, せん断速度が低い状 態から粘度減少が生じると考えられる.また, Fig. 6(a)におい て, $E=1.0 \mathrm{kV} / \mathrm{mm}$ を基準に得たモデル（実線）では異なる電 界強度のデータを十分に表していないことがわかるが，これ も shear thinning 領域が電気的モーメント, 主流によるせん断 だけでなく, 電気的不安定性が複雑に影響し相似性が失われ たと考えられる. なお，図中には後の節で用いるため， 0.5 , $1.5 \mathrm{kV} / \mathrm{mm}$ で各々フィットする様にモデル定数を定めた結果 も一点鎖線で示している. Table IIにはその際に得られたモデ ル定数も示してある.

一方, 交流電場ではLC onlyの結果に対し, 若干シフトして いるが，概ね一致する結果と見なすことができる，交流電場 下では電荷の一方向の移動が生じず, 本実験条件下では電気

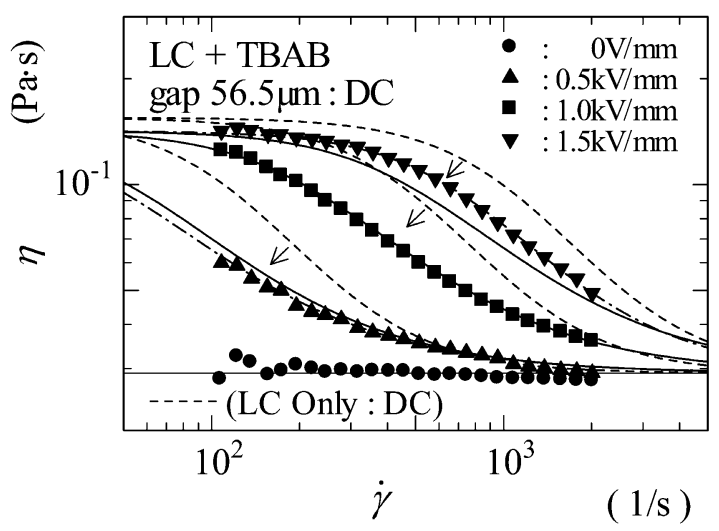

(a) DC electric field

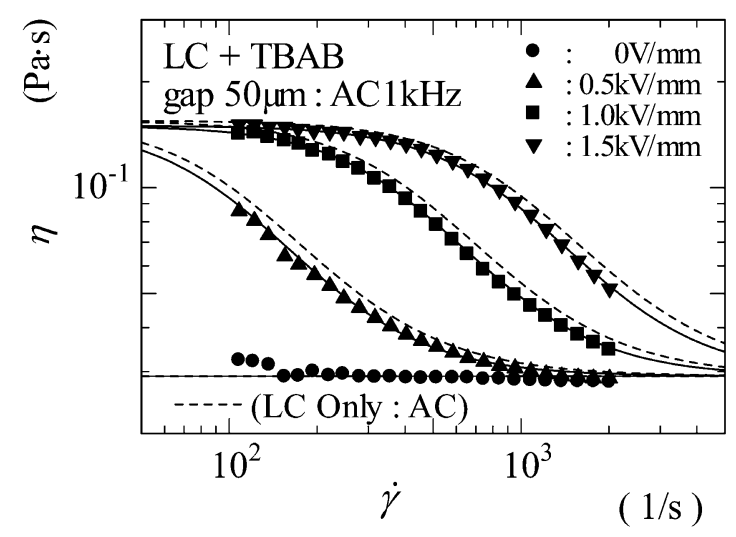

(b) AC electric field

Fig. 6. Apparent viscosity of LC+TBAB obtained with Couette Type flow. Solid lines indicate Eq. (1) estimated with parameters in Table II. The estimations in the cases of LC only (Fig. 5) are drawn with broken lines. Dot-and-dash lines in (a) are the estimations fitted to the data of respective electric field strengths.
的不安定性が生じなかったものと考えられる，よって，従来 から言われていることであるが，液晶は交流電場下での利用 の方が安定した結果が得られることが本実験の場合でも確 認された。

\section{2 二次元流路内の流れ（Poiseuille Type ) における ER 効果}

Fig. 7にLC onlyに対して2次元流路を用いて測定される流量 と圧力差から，流路内を2次元ポアズイユ流れと仮定して壁 面せん断速度と見かけの粘度を算出した結果を示す。縦軸は 液晶の無電場時の粘度 $\eta_{\mathrm{e}}$ で除した ER 効果を取っている. 図 中の実線はTable IIの定数を用いたCarreauモデルを，2次元流 路内の流れとして数值解析して得られた結果である. 数值解 析には汎用の有限要素法計算ソフトのFIDAPを用い，すきま 1 : 長さ 20 の 2 次元流路を 375 の四角形要素に分割して解析し た．実線は，実験結果に対応するせん断速度での計算結果か ら $\eta / \eta_{\mathrm{eo}}$ を算出し，それらをスプライン補間で結んだライン である.なお，図中の破線はCouette Typeの結果をそのまま重 ね合わせてみた結果である。“Type”により代表せん断速度の 定義が異なるが，実験結果Fig. 7(a)の直流電場下の結果では,

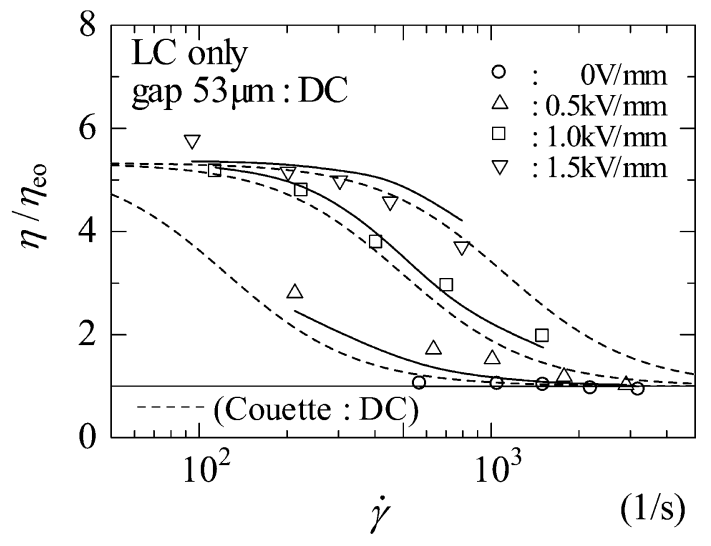

(a) DC electric field

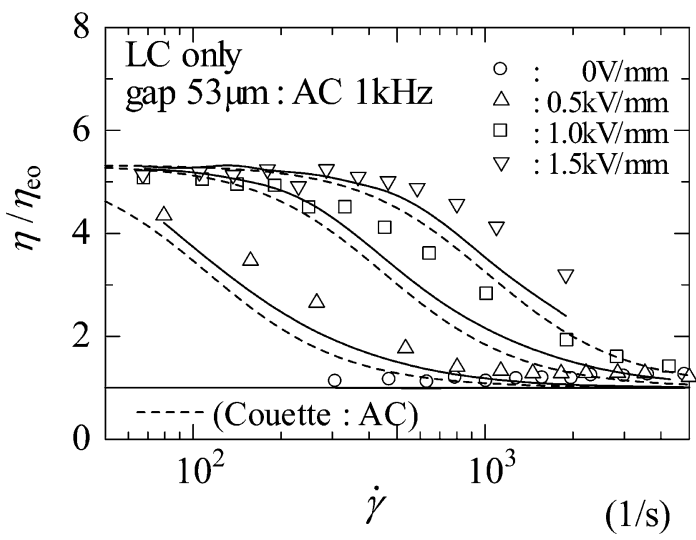

(b) AC electric field

Fig. 7. Apparent viscosity of LC only obtained with Poiseuille Type flow. Solid lines are the calculations using Eq. (1) with parameters determined from Couette Type flow. Broken lines are the estimations in the cases of Couette Type flow (Fig. 5). 
いずれの結果も概ね一致しており, Couette Typeでも Poiseuille Typeの場合でも, ER効果をほぼ一義的に扱うことができるこ とがわかる。一方，同図 (b)のACでは予測值（実線と破線） はDCの場合と同程度の一致をみるが, 実験結果自体は高せん 断側にややシフトしている. Poiseuille Typeの実験で何らかの 要因により Couette Typeの場合よりも配向の安定傾向が得ら れている事になるが，この理由は現時点では不明である. 電 極の材質などの違いもあり, 電極表面での液晶自体の拘束状 態など今後検討を要する.

LC+TBABを用いて測定した結果をFig. 8に示す．同図(a)の 実線はFig. 6の一点鎖線, すなわち各電界強度で合うように定 めたモデル定数を用いて数值解析した結果である. 実験值と 実線はほぼ一致しており，この結果からややばらつきは大き いが電気的不安定性を含む場合でもCouette Typeの実験結果 を用いれば，Poiseuille Typeの結果はほぼ予測できることがわ かる.また，交流電場の場合（Fig. 8(b)）はFig. 6の場合同様， TBAB添加の影響はほぼなく，やはり Fig. 7(b)でみられたよう に若干実験結果が左にシフトしている傾向も確認できる.

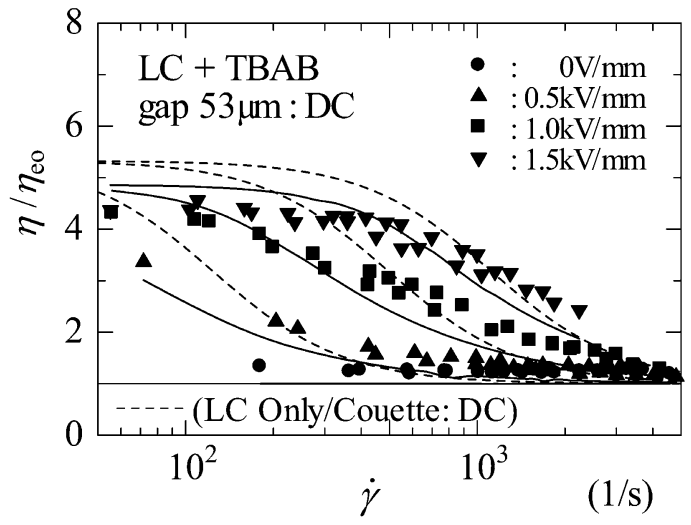

(a) DC electric field

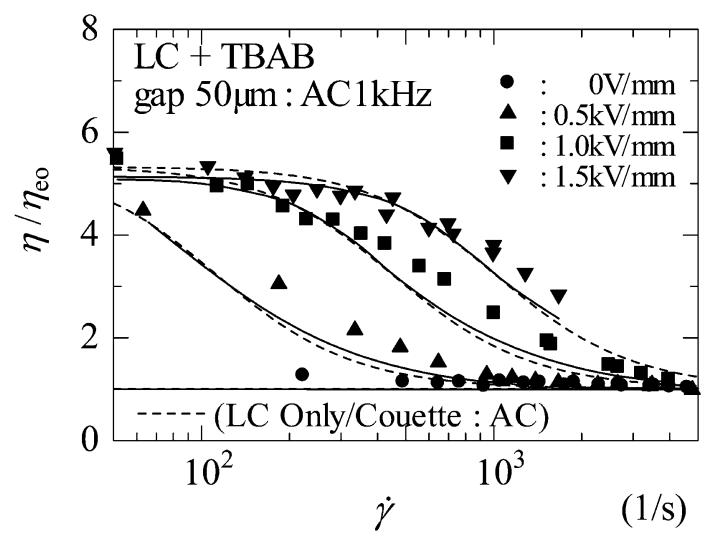

(b) AC electric field

Fig. 8. Apparent viscosity of LC+TBAB obtained with Poiseuille Type flow. Solid lines are the calculations using Eq. (1) with parameters determined from Couette Type flow under the respective conditions. Broken lines are the estimations in the cases of Couette Type flow (Fig. 6).

\section{3 電場印加時の過渡応答}

これまで定常状態での液晶のER効果について検討してき たが，応用などを考えた場合には電場印加時の応答性も問題 となる．液晶については先に述べたようにディスプレイにお ける光学的応答時間などの検討はなされているが，流動を伴 う場合の応答性については十分なデータがあるとは言い難 い，そこで，本研究では2次元流路を用いて，無電場下の流 動状態から電場印加したときの流速変化を調べた。測定結果 の例をFig. 9 に示す. 無電場時の平均流速 $V_{\mathrm{m}}$ で無次元化され た平均流速 $V$ a時間に対する変化を表しており, 時刻0(s)にお いて $1.5 \mathrm{kV} / \mathrm{mm}$ の電圧をステップ状にかけた結果となってい る. 直流，交流ならびにTBAB添加の有無によらず，Fig.9の すべてのケースでほぼ同じ応答を示していることがわかる. そして, 例えば, 電場印加後の定常值に 90 \%程度到達するま でに要する時間は概ね30-35 msである. Fig. 9の条件で光学的 応答時間 $t_{\mathrm{r}}$ もくはれを式(2), (3) で算出すると, $1 \mathrm{~ms}$ 程度の オーダーになり, この值に比較すると応答は遅いことにな る.しかし， $t_{\mathrm{r}}$ を式(2)の倍で定義する場合もあり，液晶の光

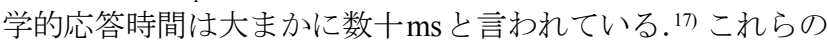
点はセルの形式，液晶材料にもよるため普遍的な議論ではな いが，流動を伴い状態が異なる本実験でも概ね近い応答をし ていると見なしてもよいと考えられる．また，この電場印加

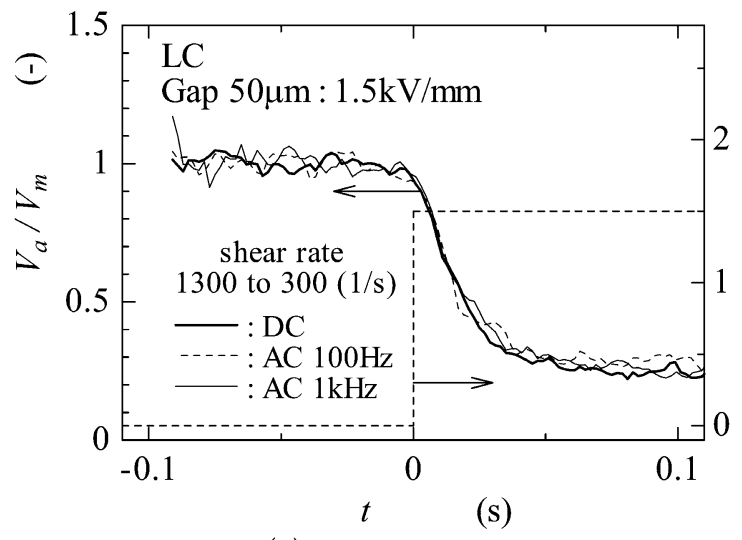

(a) LC only

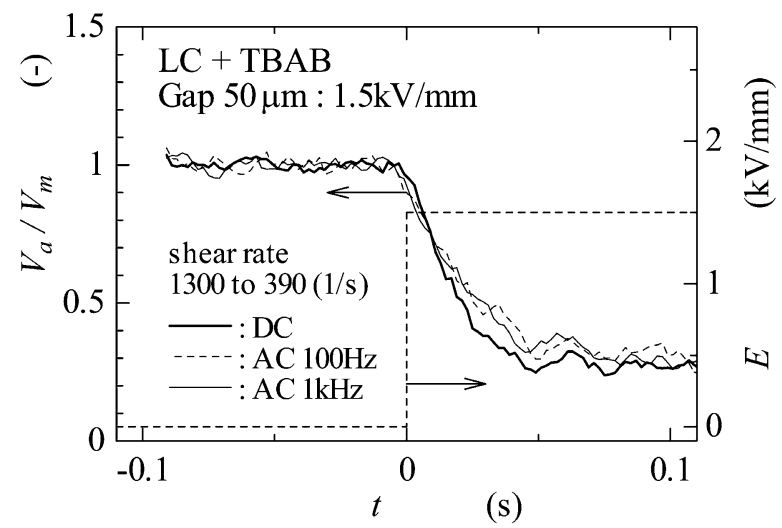

(b) LC+TBAB

Fig. 9. Transient response in mean velocity at the onset of the electric field (Poiseuille Type flow). 
による応答（流動構造の変化の過程）が TBABの有無によら ない点は，先に述べたようにDC電場下のLC+TBABも配向状 態が支配的な状態であり, LC onlyの場合と同様の構造変化が 生じているものと考えられる. なお, 本研究に用いたレオ メータでは過渡応答の測定が難しいため, Couette Typeの実験 で応答特性は測定していない.しかし，この現象には液晶分 子に加わるせん断と電場によるモーメントが支配的と考え られるため, 平均的なせん断速度が近ければ同様の結果が得 られると考えられる.

\section{4. 結 論}

液晶のER効果について shear thinning領域も含む粘度変化を 調べ, 以下の点が明らかになった. 電場下の液晶の粘度変化 はCarreau型の簡便な粘度モデルで実験式的に表すことがで き, その時定数は液晶の光学的応答時間と良好な相関があ る. 液晶の導電性が上がった場合は, 電気的不安定性が生じ ることにより直流電場下ではER効果が落ち, そのモデル化に おける時定数は一義的に定まらない. 一方, 交流電場下では 導電性の変化の影響は見られない. Couette 流れ場での測定結 果を用いることにより, Poiseuille 型の流れ場でのER効果も予 測できる. また, 電圧印加時のER効果の応答性は直流、交流 等の条件によらず, ほぼ等しく, 光学的な応答速度と概ね一 致する.

\section{謝 辞}

本研究を行うにあたり, 実験用液晶を調整・ご提供下さい ましたチッソ石油化学株式会社の宮澤和利氏はじめ関係各 位に謝意を表します.

\section{REFERENCES}

1) Jordan T, Shaw M, IEEE Trans Elect Insul, 24, 849 (1989).

2) Parthasarthy M, Klingenberg DJ, Mat Sci Eng R 17, 57 (1996).

3) See H, Korea Australia Rheology Journal, 11, 169 (1999).

4) Takesue N, Furusho J, Inoue A, J Appl Phys, 91, 1618 (2002).

5) Takesue N, Furusho J, Inoue A, J Appl Phys, 94, 5367 (2003).

6) Inoue A, Ryu U, Nishimura S, Proc 8th Int Conf on Electrorheological Fluids and Magnetorheological Suspensions, 23 (2001).

7) Miesowicz M, Nature, 158, 27 (1946).

8) Nakae T, "Engineering Rheology and Its Applications", 734 (2001), Fujitec Corp. (in Japanese)

9) Morishita S, Trans ASME, J Vib and Acoustics, 118-3, 510 (1996) .

10) Morishita S, Matsumura $Y$, Shiraishi $T$, J Japanese Society of Tribologists, 47-11, 846 (2002). (in Japanese)

11) Yoshida K, Park JH, Yano H, Yokota S, Yun S, J Sensors and Materials, 17-3, 97 (2005).

12) Matsumoto S, Kawamoto K, Tsukada T, Chem Lett, 837 (1973).

13) Matsumoto S, Tsunoda I, "Liquid Crystals - Fundamentals and Applications”, 83 (1991), Kogyo Chosakai. (in Japanese)

14) Bird RB, Armstrong RC, Hassager O, "Dynamics of Polymeric Liquids, 2nd Edition, Vol. 1", 171 (1987), Wiley.

15) Jakeman E, Raynes EP, Phys Lett, 39A, 69 (1972).

16) Sasaki N, Master Thesis, Niigata University, 31 (2005). (in Japanese)

17) Iwayanagi S, "Liquid Crystal”, 80 (1984), Kyoritsu. (in Japanese) 